\title{
ON THE INDO-EUROPEAN GENITIVE SUFFIX *-E/O
}

KENNETH SHIELDS, JR.

Esta breve nota presenta datos del griego y el celtibérico en apoyo de la hipótesis, formulada en Shields 1991, de que el indoeuropeo tenía un sufijo de genitivo en $*_{-} e / o$. Por otra parte, la nota arroja nueva luz sobre la etimología de algunas construcciones de genitivo problemáticas en esos dialectos.

Palabras clave: indoeuropeo; genitivo en -e/o
This brief paper presents data from Greek and Celtiberian to support the hypothesis presented in Shields 1991 that Indo-European possessed a genitive suffix in $*_{-e} / o$. Conversely, the paper sheds new light on the etymology of some problematic genitive constructions in these dialects.

Keywords: Indo-European; genitive suffix in -e/o

It is well known that within the Indo-European dialects thematic nouns attest a large variety of desinences as makers of the genitive case ${ }^{1}$. If one assumes the increasingly popular notion that «number ... was not consistently applied in late IE and the early dialects in accordance with natural reference» (Lehmann 1974, p. 202), i.e., that suffixes frequently showed undifferentiated singular/plural function, evident, e.g., in the singular/plural value of the Hittite genitive endings $-a \check{s}$ and -an, then the large number of exponents of the genitive function is even more dramatically manifested in this nominal class. In a series of publications (Shields 1991, 1992, 1997a, 1997b, 2000, 2001, 2003), I have attempted provide a common Indo-European source for this variation. Although the morphological material varies from dialect to dialect, I have maintained that a common Indo-European morpho-syntactic process, established by contemporary grammaticalization theory, underlies the formation of all of these genitive structures. This process recognizes that «in many, and perhaps in all, languages existential and possessive constructions derive (both synchronically and diachronically) from locatives» (Lyons 1968, p. 500, cf. also Heine 1997, p.85). Therefore,

1 The late emergence of this stem-class, just prior to the period of dialectal development (cf. Brosman 1998, p. 65), can explain the attested variation. Most certainly it does not require the omission of the genitive from the Indo-European roster of cases (Szemerényi 1996, p. 184). 
the formal identity between these genitive suffixes and traditionally reconstructed deictic particles (cf. Hirt 1927, pp. 11-13) is no coincidence; rather, this similarity belies the enclitic attachment of such deictics as a means of indicating the genitive function. Thus, in my opinion, the widely attested genitive plural suffix $*_{-o N}\left(N=m\right.$ or $n$; Skt. $-\bar{a} m$ [< $*_{-o-o n]}$ ], Lat. -um, OCS b) is a reflex of deictic $*(e / o) N)$ (Shields 1992, pp. 29-30); the genitive singular suffix $*_{-i}$ (cf. e.g., Toch. AB gen. sg. $-i<*_{-o-i}$ [Krause and Thomas 1960 , p. 105]), a reflex of the deictic $*_{i}$ (Shields 1992, p. 26); the Slavic pronominal genitive singular ending -go, a reflex of the deictic *ghe/o (Shields 1997a); the Gothic genitive plural ending $-\bar{e}$, a reflex of the deictic *e/ $/ \bar{o}$ (Shields 1997b); the Italic and Celtic genitive singular suffix $-\bar{l}$, a reflex of the deictic * (Shields 2000); the Baltic and Slavic genitive singular suffix $*-\bar{a} d$, a reflex of the contamination of deictics in $* \bar{a}$ and $*(e / o) d$; and the Tocharian genitive singular in A $-(y) \bar{a} p, \mathrm{~B}-e p i$, a reflex of the contamination of the deictics in *bh- (cf. Markey 1979, pp. 65-66) and *i (i.e., thematic vowel $*_{-}+i$ ) (Shields 2003). Even the widely attested genitive suffix $*_{-}$ (e/o)s (e.g., Skt. -as, Gk. -os, Lat. -is ) can be identified with an homophonous deictic (cf. Shields 1992, p. 29).

In Shields 1991, I used this general theory of the origin of genitive suffixes as the basis for the argument that the genitive desinences ${ }_{-s y o}$ (e.g., Skt. -sya, Faliscan -sio, Armen. -y, Hom. -oio) and *-so (e.g., Go. -i-s, OCS -so) should not be identified as pronominal genitive markers since they are commonly attested in nominal declension (e.g., Skt. vŕkkasya 'wolf', Faliscan Kaisiosio 'Caesii'; Go. wulfis [*-e-so], OHG wulfes [< $\left.{ }^{*}-o-s o\right]$ 'wolf', OP deiwas $\left[<*_{-O-S O}\right]$ 'god') and since they apparently share a common origin with other nominal genitive endings in deictic particles or the contamination of such particles ${ }^{2}$. I thus derive *-osyo from the contamination of the deictics $*(e / o) s, *_{i}$, and $* e / o$, and $*_{-s o}$ from the contamination of the deictics *(e/o)s and *e/o. Of course, this analysis implies the existence of an IndoEuropean "genitive" suffix in *-e/o. It is the purpose of this brief paper to

2 Dyen (1974: 131) and Beekes (1987: 176) also accept the original nominal provenance of *-syo, but not *-so. Beekes (1990) has more recently proposed that the genitive suffix

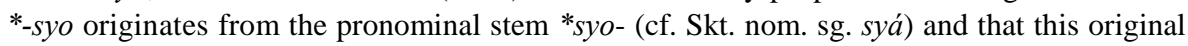
attributive form «came to function as the genitive of $*_{S O}$ » (p. 23). For a summary of newer scholarly sources regarding the origin of the $o$-stem genitive singular, see Meier-Brügger (2003, pp. 198-199).

EMERITA (EM) LXXIII 2, julio-diciembre $2005 \quad$ pp. 233-239 ISSN 0013-6662 
present additional evidence for the possible existence of an independent genitive suffix in *-e/o-evidence found especially in Greek and Celtiberian.

Before turning my attention to the Greek and Celtiberian data, I first wish to review the evidence for an Indo-European deictic in *-e/o. According to Hirt (1927, pp. 10-11), the deictic particle ${ }^{*} e / o$ «erscheint als Verbalpräfix, namentlich als Augment (gr. é-pheron, ai. á-bharam 'ich trug'), als angetretene Postposition hinter Kasusformen, z.B. ai. Dat. aśvāj-a, abg. kamen-e usw. und in ai. a-sấu 'jener', gr. ekể 'dort', wohl auch in gr. ei 'wenn', eig. 'da' $<e+i$, vielleicht auch in é-ti 'ferner', 1 . et 'und' ....e $e$-hat sich im Aind. Gen. $a-s j a$, D. $a-s m a \bar{a} i$, im Germ. ahd. $e-s$, imu, im Umbr. Dat. e-smei durch Antritt von andern Partikeln zum Pronomen entwickelt». The ablaut variant $*_{o}$ «steht [als] Verbalpräfix $o$, das namentlich im Griech. ziemlich häufig zu belegen ist. Es steckt ferner als Postposition in gr. áp-o, húp-o, ai. áp-a, úp-a, auch wohl in idg. pro» (cf. Brugmann 1916, pp. 983984). In Shields (1992, p. 27), I maintain that ${ }^{*} o$ «is also attested in the Hittite personal pronoun in $-a-$, which has its origin as a demonstrative (Sturtevant 1933, p. 198)» and which, «as is natural in an enclitic, ... shows the vowel $o$ instead of $e \gg$ (Sturtevant 1933, p. 199). I find it noteworthy that Greek so clearly attests reflexes of $* e / o$ and that Celtic preserves the deictic element in such third person (< demonstrative) pronominal forms as OIr. $\bar{e}$, $h \bar{e}$ 'he', which «sich nur aus *es, nicht wohl aus *is, erklären lässt» (Brugmann 1904, p. 35). Of course, enclitic attachment of this particle as a grammaticalized desinence would favor the $*_{O}$ variant as its realization.

Moreover, I wish to review some indirect evidence presented in Shields (1991) for a genitive marker in *-e/o. First of all, the traditional explanation of the genitive marker $*_{-s y o}$ as a contamination of the genitive suffix $*_{-S}$ and the relative pronoun $*_{-}$yo is questionable in light of Hier. Luv. gen. sg. -aši (Szemerényi 1996, p. 184), which attests the element $*_{-} i$ - without accompanying *-o, while - conversely - «Mycenaean Greek appears to show a genitive singular in -o alone (e.g., te-o ['god'], do-e-ro ['slave']), though Vilborg (1960, p. 57) argues that these forms "may be explained as showing erroneous omission of the sign -jo"» (Shields 1991, p. 58). In other words, $*_{-i \text { - and }} *_{-} O$ - seem to be independent morphological elements. Additionally, the fact that the genitive desinence ${ }^{*}$-so similarly manifests $*_{-} o$ without $*_{-} y$ - 
implies the same conclusion ${ }^{3}$.

Although this evidence is suggestive of the validity of reconstructing a genitive suffix in $*_{-e} / o$, I believe that more compelling support can be found in Greek (non-Mycenaean) and Celtiberian because these dialects may very well attest this genitive desinence in uncontaminated form. The Greek evidence, in my opinion, is to be found in the genitive singular of the masculine $\bar{a}$ - stems (cf., e.g., Hom. $-\bar{a}-o$ ). Of course, this construction has been explained in a variety of ways. Traditionally, it has been asserted that «inherited $-\bar{a} s$ was replaced by $-\bar{a} o$, with $-o$ taken over from the final of the $o$-stem gen., -oio, -oo $\left[<*_{-o-s y o}\right.$. This was long explained as early $\mathrm{G} *_{-y o}$ abstracted from masc. *-o-yo and grafted onto the stem-vowel $-\bar{a}-$, whence $*_{-} \bar{a} y o>$ $-\bar{a} o »$ (Sihler 1995, p. 274). Yet, since the suffix $-a-o$, and not expected $-a-j o$, is attested in the masculine $\bar{a}$-stems of Mycenaean, the traditional etymology has become less favored ${ }^{4}$. Lillo (1987), cf. Geiss (1956), argues that *-a o derives from «the influence of pronominal ending *-oo» (p. 255), itself derived from*-o-so, the stem vowel plus the so-called pronominal genitive in *-so, while in Shields (1991, p. 59), I raise the possibility that it may originate from the direct affixation of $*_{-s o}$ to $*_{-} \bar{a}$, since $*_{-s o}$ was not exclusively pronominal in its distribution. Although this latter explanation remains feasible, another etymology should be acknowledged in the context of my view of the widespread morpho-syntactic process which gave rise to genitive markers - simply, Greek - $\bar{a} o$ may reflect the direct affixation of the deictic element $*_{-} o$ to the stem-vowel $*_{-} \bar{a}$. The motivation for this addition could simply have been the attempt to establish the formal differentiation of this special class of masculine nouns within the largely feminine stem-class. Indeed, this tendency towards formal differentiation includes the nominative singular as well, marked by $-\bar{a} s$ instead of expected $-\bar{a}$. Phonologically, too, this alternative hypothesis is sound. Sihler (1995, pp. 274-275) emphasizes

3 The wide applicability of the process which I hypothesize as the basis of the formation of genitive suffixes causes me to reject the theory promoted by Rix (1988, p. 107) that $*_{-s o}$, as a parallel to $*_{-s y o}$, represents the genitive suffix $*_{-s}$ with an affixed anaphoric demonstrative pronoun in $*_{-} o$.

4 Sihler (1995, p. 274) notes that qualifications have been added to the traditional theory in order to save it in the face of the Mycenaean data. Thus, for example, it has been proposed «that intervocalic $-y$ - dropped earlier after long vowels than after short ones, disrupting the parallelism of orig. -oyo and *-ayo» or «that the singular was influenced by the form of the plural, that is *-āhon.»

EMERITA (EM) LXXIII 2, julio-diciembre 2005 pp. 233-239 ISSN 0013-6662 
that although Homeric Greek, for example, contracts *-ae to $-\bar{a}$, this by no means implies that theories involving the direct addition - through analogy or otherwise - of $*_{-} o$ to $*_{-} \bar{a}$ are rendered implausible since the parallelism between the constructions «is indirect evidence indeed». In short, the early Greek replacement of the genitive singular $\bar{a}$-stem suffix $*_{-} \bar{a} s$ by $*_{-} \bar{a} o$ was, in my view, not motivated by analogy or, necessarily, by the affixation of *-so to the stem; instead, it could easily reflect a common, inherited IndoEuropean morpho-syntactic process whereby ${ }_{-}-o$, by virtue of its deictic status, was enclitically affixed to $*_{-} \bar{a}$ as a grammaticalized genitive element.

I feel that this analysis of the Greek data is strengthened by comparative evidence from Celtiberian, which attests an $o$-stem genitive singular suffix in $-o$. According to Schmidt (1992, p. 48), as far as the etymology of the desinence is concerned, «the best explanation up to now seems to be the derivation of this $-o$ from the ending of the ablative singular in $*_{-}-\bar{d} d(\mathrm{cf}$. Villar 1989, p. 201) ${ }^{5}$. This desinential element stands in contrast to the suffix $*_{-} \bar{l}$ which possesses genitive singular value in the other Celtic languages, and it provides testimony to the inflectional variation within dialects regarding the exponents of the genitive case - variation which is also evident in the $o$ - stems of Latin $(-\bar{l})$ as compared to its Italic counterpart Faliscan $(-o s i o)^{6}$. Again, I find Schmidt's hypothesis reasonable (cf. Shields 2001, p. 165), but it most certainly is not a necessary assumption. Villar (1989) argues convincingly that Indo-European ${ }^{*} \bar{o}$ - becomes $-\bar{u}$ - in final syllables in Celtiberian, except when it appears in absolute final position, in which case it is retained. This leads him to propose that «la final $*_{-}-\bar{d}$ ha perdido su $*_{-} d$, pero la vocal $-\bar{o}$ - en final absoluta que secundariamente de ello resulta no ha visto alterar su timbre ni siquiera en los textos más recientes» (p. 205). In

5 Schmidt (1992, p. 53n.26) draws a parallel between the Celtiberian suffix and the genitive suffix of Baltic and Slavic, which he reconstructs as $*_{-}-\bar{d}$, not $*_{-} \bar{a} d$.

${ }^{6}$ Other explanations of Celtiberian -o have been offered. Eska (1989, p. 160), for example, derives the suffix from ${ }^{*}-o s$ and says: «It appears that $*_{-s}$ has been suppressed, perhaps on the model of forms that had lost $*_{-s}$ due to sandhi, in order to disambiguate the masc. nom. and gen. sg. Neut. gen. sg. -os <*-os, found in ToCoiToś ..., preserved the sibilant because there was no ambiguity between the nom. and gen. sg.». The complicated morphological conditioning of this sound change, though possible, makes it less likely as a viable explanatory basis for the etymology of the suffix. In an early paper on this topic, Untermann (1967) traces the origin of the Celtiberian genitive ending to $*_{-s o}$ or $*_{-s y o}-\mathrm{a}$ view which is difficult to defend phonologically.

EMERITA (EM) LXXIII 2, julio-diciembre $2005 \quad$ pp. 233-239 ISSN 0013-6662 
my opinion, the Celtiberian genitive suffix in $-o$ can be derived from the affixation of the deictic particle $*_{o}$ to the stem vowel, i.e., $*_{-}-o$, with a resulting contraction to $*_{-} \bar{o}$. This genitive construction in $*_{-} \bar{o}$ is thus primarily, not secondarily, word-final; and it is therefore preserved as $-o$ in the dialect $^{7}$.

I recognize that the hypothesis presented here cannot be proven absolutely correct. However, I would most certainly maintain that the extant data and recognized patterns of linguistic change render it plausible and therefore worthy of consideration as a reasonable alternative reconstruction.

\section{REFERENCES}

Adrados, F. R., 1992: «The New Image of Indoeuropean: The History of a Revolution», Indogermanische Forschungen 97, pp. 1-28.

Beekes, 1987: «The Origin of the Indo-European Dative-Locative Singular Endings», A Festschrift in Honor of Edgar C. Polomé, eds. M. A. Jazayery \& W. Winter, Berlin, pp. 29-42.

—, 1990: «The Genitive in *-osio», Folia Linguistica Historica 11, pp. 21-25.

Brosman, P., 1998: «On the Origin of PIE o-Stems», Folia Linguistica Historica 19, pp. 65-78.

Brugmann, K., 1904: Die Demonstrativpronomina der indogermanischen Sprachen, Leipzig.

—, 1916: Grundriss der vergleichenden Grammatik der indogermanischen Sprachen, vol. 2.3, Strassburg, Trübner.

Dyen, I., 1974: «Genetic Classification and Affix Reconstruction: The PIE Ending of the Genitive Singular of $O$-Stem Nouns», Historical Linguistics II: Theory and Description in Phonology, eds. J. Anderson \& C. Jones, Amsterdam, Benjamins, pp. 123-139.

Eska, J., 1989: Towards an Interpretation of the Hispano-Celtic Inscription of Botorrita, Innsbruck.

Geiss, H., 1956: «Zum Genetiv der Maskulina der $\bar{a}$-Deklination auf -āo», Glotta 35, pp. 142-144.

Heine, B., 1997: Possession: Cognitive Sources, Forces, and Grammaticalization, Cambridge.

Hirt, H., 1927: Indogermanische Grammatik, vol. 1, Heidelberg.

Krause, W. \& W. Thomas, 1960: Tocharisches Elementarbuch, vol. 1, Heidelberg.

7 In Celtiberian script the same symbol represents $o$ and $\bar{o}$ (Villar 1989, p. 200).

EMERITA (EM) LXXIII 2, julio-diciembre 2005 pp. 233-239 ISSN 0013-6662 
Lillo, A., 1987: «Notes on the Singular Genitive of Greek Masculine *a Stem Nouns», KZ101, pp. 249256.

Lehmann, W. P., 1974: Proto-Indo-European Syntax, Austin.

Lyons, J., 1968: Introduction to Theoretical Linguistics, Cambridge.

Markey, T. L., 1979: «Deixis and the $u$-Perfect», JIES7, pp. 65-76.

Meier-Brügger, M., 2003: Indo-European Linguistics, Berlin.

Rix, H., 1988: «The Proto-Indo-European Middle: Content, Forms and Origin», MSS 49, pp. 101-119.

Schmidt, K. H., 1992: «Contributions from New Data to the Reconstruction of the Proto- Language», Reconstructing Languages and Cultures, eds. E. Polomé \& W. Winter, Berlin, pp. 35-62.

Shields, K., 1991: «Comments about the $o$-Stem Genitive of Indo-European», Historische Sprachforschung 104, pp. 52-62.

—, 1992: A History of Indo-European Verb Morphology, Amsterdam.

-, 1997a: «On the Origin of the Slavic Pronominal Genitive Singular Ending -go», International Journal of Slavic Linguistics and Poetics 41, pp. 83-91.

- 1997b: «The Gothic Genitive Plural in *-e Revisited», American Journal of Germanic Linguistics and Literature 9, pp. 239-249.

— 2000: «Indo-European $o$-Stem Genitives in *-̄», Lingua Posnaniensis 42, pp. 145-150.

—, 2001: «On the Origin of the Baltic and Slavic $o$-Stem Genitive Singular Suffix ${ }^{*}-\bar{a} d »$, Baltistica 36.2, pp. 165-171.

—, 2003: «On Tocharian Genitives in A -(y)āp, B -epi», Tocharian and Indo-European Studies 10, pp. 97 103.

Sihler. A. L., 1995: New Comparative Grammar of Greek and Latin, Oxford.

Sturtevant, E. H., 1933: A Comparative Grammar of the Hittite Language, Philadelphia.

Szemerényi, O., 1996: Introduction to Indo-European Linguistics, 4th ed., Oxford.

Untermann, J., 1967: «Die Endung des Genetiv singularis der -o-Stämme im Keltiberischen», Beiträge zur Indogermanistik und Keltologie, ed. W. Meid, Innsbruck, pp. 281-288.

Vilborg, E., 1960: A Tentative Grammar of Mycenaean Greek, Göteborg, Elanders Boktryckeri Aktiebolag.

Villar, F., 1989: «Tratamiento de -ō en sílaba final: Algunas posibles formas de imperativo en Celtibérico», Veleia 6, pp. 199-205.

Con arreglo a las normas editoriales vigentes para las publicaciones periódicas del CSIC, se hace constar que el original de este artículo se recibió en la redacción de EMERITA en el primer semestre de 2005, siendo aprobada su publicación en ese mismo período.

EMERITA (EM) LXXIII 2, julio-diciembre $2005 \quad$ pp. 233-239 ISSN 0013-6662 